\title{
AKTUALISASI TATA NILAI 'PASTI' DALAM MEWUJUDKAN WILAYAH BEBAS DARI KORUPSI SERTA WILAYAH BIROKRASI BERSIH DAN MELAYANI
}

(Actualization of the 'PASTI' Value in Creating Corruption-Free and Clean and Serving Bureaucratic Areas)

\author{
Edward James Sinaga \\ Pusat Pengkajian dan Pengembangan Kebijakan \\ Badan Penelitian dan Pengembangan Hukum dan Hak Asasi \\ Manusia Kementerian Hukum dan Hak Asasi Manusia Republik \\ Indonesia Jalan HR Rasuna Said Kav 4-5 Kuningan, Jakarta Selatan \\ 12940 Telepon (021) 2525015 Faksimili (021) 2526438 \\ edwardjames88@ymail.com
}

Tulisan diterima: 16 Januari 2019; Direvisi: 6 Maret 2019;

Disetujui Diterbitkan: 13 Maret 2018

DOI: http://dx.doi.org/10.30641/kebijakan.2019.V13.31-50

\begin{abstract}
Abstrak
Pencanangan wilayah bebas dari korupsi di Kementerian Hukum dan Hak Asasi Manusia dimulai sejak tahun 2004 sampai sekarang. Namun, dari 814 unit kerja hanya satu unit kerja yang telah memperoleh predikat Wilayah Bebas dari Korupsi pada tahun 2016, yaitu Lembaga Pemasyarakatan Perempuan Semarang. Kemudian, pada tahun 2018 menjadi 11 satuan kerja yang predikat Wilayah Bebas dari Korupsi. Untuk percepatan pemberantasan dan pencegahan korupsi dilakukan gerakan revolusi mental "Ayo Kerja, Kami PASTI“. Untuk itu dianalisis Aktualisasi Tata Nilai 'PASTI' dalam pelaksanaan tugas dan fungsi dari satuan kerja dengan menggunakan pendekatan kualitatif. Setelah pendeklarasian Tata Nilai 'PASTI' sikap dan tindakan yang dilakukan berbeda dengan sebelum pendeklarasian, seperti sikap tepat waktu. Ketaatan terhadap jam masuk kerja dan jam keluar kerja sudah lebih tepat waktu, serta penyelesaian pekerjaan sesuai dengan aturan yang ditetapkan. Unit kerja telah mengimplementasikan seluruh 'aturan disiplin'/'kode etik'/'kode perilaku' pegawai yang ditetapkan organisasi namun belum membuat inovasi yang sesuai dengan karakteristik unit kerja. Masih ada unit kerja yang belum melengkapi Standar Operasi Prosedur dan masih kurangnya data pendukung di setiap kegiatan yang dilakukan. Serta belum adanya dukungan khusus anggaran dan reward bagi unit kerja penerima predikat wilayah bebas dari korupsi.
\end{abstract}

Kata kunci: aktualisasi; tata nilai; wilayah bebas dari korupsi.

\section{Abstract}

The idea of corruption-free areas staged by the Ministry of Law and Human Rights had its start since 2004 until now. However, from 814 work units, there is only one work unit that has been labeled the Corruption-free Area, the Semarang Women's Correctional Institute. To accelerate corruption eradication and prevention, a mental revolution movement "Ayo Kerja, Kami PASTI" or literally "Let's get work, we are PASTI" has been created. For such purpose the actualization of certainty value of the word "PASTI" should be analyzed when performing the tasks and functions of the work unit using a qualitative approach. Following the declaration of the certainty value of the word 'SURE', attitudes and actions should have differed from that time before such declaration, such as attitude toward time punctuality. Compliance with work hours regulation should be higher and the jobs done in a manner that is more compliance with the laws and regulations. The work unit has applied all 'laws and regulations of discipline' / 'code of ethics' / 'code of conduct' to the employees appointed by the organization who have not yet made innovations that fit the characteristics of the work unit. Some work units have not yet had their complete Standard Operating Procedures and lacked of supporting 
Volume 13, Nomor 1, Maret $2019: 31-50$

data in their activity. Also, there has been no special support in the forms of budgets and rewards for the work units that have been labeled a corruption-free area.

Keywords: actualization; values; corruption-free areas.

\section{PENDAHULUAN}

\section{Latar Belakang}

Efektivitas dan keberhasilan pembangunan terutama ditentukan oleh dua faktor, yaitu sumber daya manusia dan pembiayaan. Diantara dua faktor tersebut yang paling dominan adalah faktor sumber daya manusia. Rendahnya kualitas sumber daya manusia berimplikasi langsung terhadap tugas dan fungsi yang diembannya. Kualitas tersebut bukan hanya dari segi pengetahuan atau intelektual saja, akan tetapi juga menyangkut kualitas moral dan kepribadiannya. Rapuhnya moral dan rendahnya tingkat kejujuran dari aparat penyelenggara negara menyebabkan terjadinya korupsi. Korupsi di Indonesia dewasa ini sudah merupakan pathology social (penyakit sosial) yang sangat berbahaya yang mengancam semua aspek kehidupan bermasyarakat, berbangsa dan bernegara.

Korupsi telah mengakibatkan kerugian keuangan negara yang sangat besar. Hal itu merupakan cerminan rendahnya moralitas dan rasa malu, sehingga yang menonjol adalah sikap kerakusan dan aji mumpung. Persoalannya adalah dapatkah korupsi diberantas? Tidak ada jawaban lain kalau kita ingin maju, korupsi harus diberantas. Jika kita tidak berhasil memberantas korupsi, atau paling tidak mengurangi sampai pada titik nadir yang paling rendah maka jangan harap Negara yang kita cintai ini akan mampu mengejar ketertinggalannya dibandingkan

negara lain untuk menjadi sebuah negara yang maju. Untuk mengurangi perilaku yang koruptif suatu organisasi harus menanamkan nilai-nilai dan mengaktualisasikan nilai tersebut.
Aktualisasi merupakan suatu bentuk kegiatan melakukan realisasi antara pemahaman akan nilai dan norma dengan tindakan dan perbuatan yang dilakukan dalam kehidupan sehari-hari. Sedangkan aktualisasi tata nilai berarti penjabaran nilainilai dalam bentuk norma-norma, serta merealisasikannya. Sehingga dapat menuju suatu kodisi yang diharapkan, yaitu Wilayah Bebas dari Korupsi (WBK) dan Wilayah Birokrasi Bersih dan Melayani (WBBM).

WBK adalah predikat yang diberikan kepada suatu unit kerja yang memenuhi sebagian besar manajemen perubahan, penataan tata laksana, penataan sistem manajemen SDM, penguatan pengawasan, dan penguatan akuntabilitas kinerja. Sementara WBBM adalah predikat yang diberikan kepada suatu unit kerja yang memenuhi sebagian besar manajemen perubahan, penataan tata laksana, penataan sistem manajemen SDM, penguatan pengawasan, penguatan akuntabilitas kinerja, dan penguatan kualitas pelayanan publik. ${ }^{1}$

Korupsi di Indonesia telah berkembang dalam 3 (tiga) tahap yaitu elitis, endemik, dan sistematik. Pada tahap elitis, korupsi masih menjadi pathology social yang khas di lingkungan para elit/pejabat. Pada tahap endemik, korupsi mewabah menjangkau lapisan masyarakat luas. Lalu di tahap yang kritis, ketika korupsi menjadi sistemik, setiap individu di dalam sistem terjangkit penyakit yang serupa. Penyakit korupsi di Indonesia

Indonesia, Peraturan Menteri PAN dan RB Nomor Nomor 52 Tahun 2014 Tentang Pedoman Pembangunan Zona Integritas Menuju Wilayah Bebas Dari Korupsi Dan Wilayah Birokrasi Bersih Dan Melayani di Lingkungan Instansi Pemerintah, Jakarta. 
ini telah sampai pada tahap sistematik. Perbuatan korupsi merupakan pelanggaran terhadap hak-hak sosial dan hak-hak ekonomi masyarakat, sehingga korupsi tidak dapat lagi digolongkan sebagai kejahatan biasa (ordinary-crimes). Dalam upaya pemberantasannya tidak lagi dapat dilakukan "secara biasa", tetapi dituntut cara-cara yang "luar biasa" (extra-ordinary enforcement).

Kementerian Hukum dan Hak Asasi Manusia (Kemenkumham) meski memiliki potensi dalam mendukung pencapaian tujuan dan sasaran pembangunan nasional namun masih memiliki hambatan dan permasalahan untuk memaksimalkan potensi yang dimiliki. ${ }^{2}$ Hambatan dan permasalahan tersebut berkaitan dengan kesiapan pelaksanaan perubahan organisasi terhadap pembangunan Aparatur Negara yang merupakan wujud dari kelanjutan keberhasilan pelaksanaan Reformasi Birokrasi melalui Undang-undang No.5 Tahun 2014, tentang Aparatur Sipil Negara. $^{3}$

Dari sisi pengawasan, Inspektorat Jenderal menyebutkan bahwa masih terjadinya praktek korupsi, kolusi dan nepotisme atau irregularities di lingkungan Kemenkumham karena kurangnya penegakan aturan, lemahnya pengawasan secara berjenjang dari atasan, dan kurangnya upaya-upaya pencegahan korupsi, kolusi dan nepotisme. ${ }^{4}$

Dalam upaya pemberantasan korupsi, pada tanggal 9 Desember 2004 Pemerintah Indonesia telah menerbitkan Instruksi

2 Lampiran Peraturan Menteri Hukum dan Hak Asasi Manusia Republik Indonesia Nomor 7 tahun 2015 Tentang Rencana strategis Kementerian Hukum dan Hak Asasi Manusia Tahun 2015 2019, hlm. 41.

3 Rr. Susana A.M., Implementasi Peningkatan Kinerja Melalui Merit Sistem Guna Melaksanakan Undang-Undang Aparatur Sipil Negara No.5 Tahun 2014 di Kementerian Hukum dan HAM, Jurnal IImiah kebijakan Hukum Volume 10, Nomor 2, Juli 2016, hlm.186.

4 Renstra Kemenkumham, Op. Cit., hIm. 43.
Presiden Nomor 5 Tahun 2004 (Inpres No. 5 Tahun 2004) tentang Percepatan Pemberantasan Korupsi. Secara umum instruksi ini memerintahkan kepada para pembantu Presiden untuk melakukan berbagai upaya percepatan pemberantasan korupsi, yang dimulai dari internal pemerintah. Selain itu, Pemerintah Indonesia juga mengeluarkan Peraturan Pemerintah Nomor 60 Tahun 2008 tentang Sistem Pengendalian Internal Pemerintah (Lembaran Negara Republik Indonesia Tahun 2008 Nomor 127, Tambahan Lembaran Negara Republik Indonesia Nomor 4890).

Fakta dalam pelaksanaan tugas dan fungsi masih melakukan kegiatan tanpa bersinergi dengan unit satuan kerja yang lain. Padahal bekerja membutuhkan sinergi yaitu keterhubungan, konsistensi dan keselarasan yang terjalin antara Satuan kerja. Bersinergi tidak hanya dalam alur koordinasi tetapi semua hal yang berhubungan dengan pengorganisasian. Selain itu juga diperlukan inovasi yang dapat mengubah organisasi ke arah yang lebih baik, karena untuk bisa mempertahankan keberadaan organisasi dalam jangka panjang perlu melakukan inovasi. Hingga saat ini upaya berkelanjutan (continuous innovation) sangat jarang terjadi. Pegawai hanya berinovasi jika memang diharuskan. Selain itu, pegawai juga sulit meninggalkan ide lama.

Salah satu upaya pencegahan korupsi yang paling efektif selain penindakan adalah penguatan penyelenggaraan Sistem Pengendalian Intern Pemerintah. Sistem Pengendalian Intern (SPI) adalah proses yang integral pada tindakan dan kegiatan yang dilakukan secara terus menerus oleh pimpinan dan seluruh pegawai untuk memberikan keyakinan memadai atas tercapainya tujuan organisasi melalui kegiatan yang efektif dan efisien, keandalan pelaporan keuangan, pengamanan aset negara, dan ketaatan terhadap peraturan perundang- 
undangan. SPI yang diselenggarakan secara menyeluruh di lingkungan pemerintah pusat dan pemerintah daerah disebut SPI Pemerintah (SPIP). SPIP wajib dilaksanakan oleh menteri/pimpinan lembaga, gubernur, dan bupati/ walikota untuk mencapai pengelolaan keuangan negara yang efektif, efisien, transparan, dan akuntabel. Jika dilaksanakan dengan baik dan benar, SPIP akan memberi jaminan dimana seluruh penyelenggara negara mulai dari pimpinan hingga pegawai di instansi pemerintah akan melaksanakan tugasnya dengan jujur dan taat pada peraturan. Dengan demikian, tidak akan terjadi penyelewengan yang dapat menimbulkan kerugian negara. Salah satu indikator keberhasilan penerapan SPIP adalah keandalan dalam Laporan Keuangan Pemerintah Pusat (LKPP), Laporan Keuangan Kementerian/Lembaga (LKKL), dan Laporan Keuangan Pemerintah Daerah (LKPD). Dengan penerapan SPIP diharapkan akan dapat diwujudkan pengelolaan keuangan negara yang profesional, efektif, efisien, transparan, dan akuntabel.

\section{Menindaklanjuti Instruksi Presiden} Nomor 5 Tahun 2004 dan Peraturan Pemerintah Nomor 60 Tahun 2008 tersebut, Kemenkumham telah melakukan langkahlangkah menuju terwujudnya Wilayah Bebas dari Korupsi dan Wilayah Birokrasi Bersih dan Melayani (WBK dan WBBM). Namun, sejak pencanangan wilayah bebas korupsi mulai tahun 2004 sampai saat ini, dari 814 satuan kerja yang ada di Kemenkumham ${ }^{5}$ hanya satu unit kerja/satuan kerja yang telah

5 Kementerian Hukum dan Hak Asasi Manusia terdiri dari 814 satuan kerja yang meliputi 11

Unit Eselon I, 33 Kantor Wilayah, 5 Balai Harta Peninggalan, 121 Kantor Imigrasi, 13 Rumah Detensi Imigrasi, 18 Perwakilan RI di Luar Negeri, 263 Lembaga Pemasyarakatan, 215 Rumah Tahanan Negara, 71 Balai Pemasyarakatan, 63 Rumah Penyimpanan Barang Sitaan Negara dan 1 Rumah Sakit. Jumlah Pegawai Kementerian Hukum dan Hak Asasi Manusia sebanyak 44.178 orang (Per Juni 2014). memperoleh predikat WBK pada tahun 2016, yaitu Lembaga Pemasyarakatan Perempuan Semarang. Kemudian pada tahun 2018 bertambah 10 unit kerja/satuan kerja yang berpredikat $\mathrm{WBK}^{6}$. Tentu ini menjadi "pekerjaan rumah" Kemenkumham untuk menyelesaikan problema ini, sehingga unit kerja/satuan kerja lainnya dapat memperoleh predikat WBK/WBBM.

Seperti diketahui, Kemenkumham merupakan Kementerian ke-5 yang mencanangkan sebagai Zona Integritas (ZI) menuju Wilayah Bebas dari Korupsi. Kemenkumham mencanangkan pembangunan zona integritas menuju WBK sejak tanggal 21 Juni 2012 pada 17 kantor wilayah. Pencanangan tersebut ditandai dengan penandatanganan piagam pencanangan ZI oleh Menkumham disaksikan oleh Menteri Pendayagunaan Aparatur Negara dan Reformasi Birokrasi, Ketua KPK, dan Ketua Ombudsman. Pencanangan tersebut sebelumnya telah didahului dengan penandatanganan Pakta Integritas oleh seluruh pegawai, pejabat di lingkungan Kemenkumham.

Proses Pembangunan Zona Integritas (ZI) Menuju WBK dan WBBM adalah Proses pembangunan Zona Integritas sebagai tindak lanjut pencanangan yang telah dilakukan oleh pimpinan instansi pemerintah. Proses pembangunan Zona Integritas difokuskan pada penerapan program Manajemen Perubahan, Penataan Tatalaksana, Penataan Manajemen SDM, Penguatan Pengawasan, Penguatan Akuntabilitas Kinerja, dan Peningkatan Kualitas Pelayanan Publik yang bersifat konkret. Dalam membangun Zona

\footnotetext{
$\overline{6}$ Kementerian Hukum dan HAM. "Refleksi Akhir Tahun Kemenkumham, Yasonna Beri Penghargaan 10 Satker Berpredikat WBK". In https://kemenkumham.go.id/berita/refleksiakhir-tahun-kemenkumham-yasonna-beripenghargaan-10-satker-berpredikat-wbk. Last update by 27 December 2018, Last access by 15 March 2019
} 
Integritas, pimpinan instansi pemerintah menetapkan satu atau beberapa unit kerja yang diusulkan sebagai WBK/WBBM.

Predikat menuju WBK adalah predikat yang diberikan kepada unit kerja/satuan kerja yang memenuhi sebagian besar manajemen perubahan, penataan tatalaksana, penataan Sistem Manajemen SDM, penguatan pengawasan, dan penguatan akuntabilitas kinerja, sedangkan predikat menuju WBBM adalah predikat yang diberikan kepada suatu unit kerja/satuan kerja yang sebelumnya telah mendapat predikat menuju WBK dan memenuhi sebagian besar manajemen perubahan, penataan tatalaksana, penataan sistem manajemen SDM, penguatan pengawasan, penguatan akuntabilitas kinerja, dan penguatan kualitas pelayanan publik. Pemilihan unit kerja/satuan kerja yang diusulkan mendapat predikat WBKMBBM memperhatikan beberapa syarat yang telah ditetapkan, diantaranya 1) Setingkat eselon I sampai dengan eselon III, 2) Dianggap sebagai unit kerja yang penting/ strategis dalam melakukan pelayanan publik, 3) Mengelola sumber daya yang cukup besar, serta 4) Memiliki tingkat keberhasilan reformasi birokrasi yang cukup tinggi di unit kerja/satuan kerja tersebut.

Untuk memperkuat pencegahan dan pemberantasan korupsi selanjutnya pemerintah mengeluarkan Peraturan Pemerintah Nomor 55 Tahun 2012 tentang Strategi Nasional Pencegahan dan Pemberantasan Korupsi Jangka Panjang Tahun 2012-2025 dan Jangka Menengah tahun 2012-2014. Dalam Pasal 3 Peraturan Pemerintah Nomor 55 Tahun 2012 mengamanahkan bahwa "Kementerian/ Lembaga dan Pemerintah Daerah menjabarkan dan melaksanakan Strategi Nasional Pencegahan dan Pemberantasan Korupsi sebagaimana dalam Pasal 2, melalui AksiPencegahan dan PemberantasanKorupsi (PPK) yang ditetapkan setiap 1 (satu) tahun".
Kemudian pada Instruksi Presiden Nomor 2 tahun 2014 tentang Aksi Pencegahan dan Pemberantasan Korupsi tahun 2014 dalam diktum ketiga dijabarkan bahwa "Aksi PPK tahun 2014 sebagaimana dimaksud dalam diktum pertama, berpedoman pada strategistrategi: pencegahan, penegakan hukum, peraturan perundang-undangan, kerjasama internasional dan penyelamatan aset hasil korupsi, pendidikan dan budaya anti korupsi, dan mekanisme pelaporan.

Kemudian untuk penetapan unit kerja/ satuan kerja yang berstatus WBK, Menteri Hukum dan HAM mengeluarkan Peraturan Menteri Hukum dan HAM (Permenkumham) Nomor M.HH-01.PW.02.03 Tahun 2011 tentang Pedoman Penetapan Wilayah Bebas Korupsi (WBK) Kementerian Hukum dan HAM. Dalam Pasal 3 Permenkumham ini dijelaskan bahwa ruang lingkup pelaksanaan WBK di lingkungan Kementerian Hukum dan HAM, meliputi: penerapan sistem pengendalian intern pemerintah, komitmen pimpinan unit kerja terhadap percepatan pemberantasan dan pencegahan korupsi, penetapan kinerja, penetapan area WBK, serta monitoring dan evaluasi. Sedangkan dalam Pasal 8 dikatakan bahwa Inspektorat Jenderal melaksanakan monitoring, evaluasi, dan penilaian atas laporan pelaksanaan WBK dan hasilnya dilaporkan kepada Menteri untuk ditetapkan sebagai unit kerja WBK.

Pencanangan program aksi untuk Percepatan Pemberantasan dan Pencegahan Korupsi, serta Gerakan Revolusi Mental pada Kabinet Kerja sesuai dengan Direktif Presiden melalui jalan perubahan JOKOWI-JK untuk rakyat Indonesia, yang berisikan 3 (tiga) aspek perubahan yaitu: menghadirkan negara yang bekerja, kemandirian yang mensejahterakan, dan revolusi mental. Seiring dengan itu Kemenkumham melalui Peraturan Menteri Hukum dan Hak Asasi Manusia Republik Indonesia Nomor 7 tahun 2015 Tentang Rencana Strategis Kementerian Hukum dan 
Hak Asasi Manusia Tahun 2015-2019 juga telah melakukan Gerakan Revolusi Mental "Ayo Kerja, Kami PASTI". Akronim 'PASTI' merupakan singkatan dari Profesional, Akuntabel, Sinergi, Transparan, dan Inovatif. Manfaat yang diperoleh dari Gerakan Revolusi Mental "Ayo Kerja, Kami PASTI" ini adalah seluruh aparatur Kemenkumham menjadi manusia yang sehat, cerdas, dan berkepribadian, sehingga mampu berperan aktif dalam mensukseskan sasaran pembangunan nasional yang diemban oleh Kemenkumham.

Program aksi untuk percepatan pemberantasan dan pencegahan korupsi yang telah diatur dengan beberapa peraturan perundang-undangan dan gerakan revolusi mental "Ayo Kerja, Kami PASTI" yang telah dicanangkan di Kemenkumham seharusnya terdapat benang merah yang saling bersinergi antara tata nilai 'PASTI' dengan Pemberantasan dan Pencegahan Korupsi (PPK) dalam suatu wadah yang disebut WBK dan WBBM. Sehubungan dengan itu dipandang perlu dilakukan suatu Penelitian tentang: Aktualisasi Tata Nilai 'PASTI' untuk mewujudkan WBK dan WBBM di lingkungan Kemenkumham.

\section{Rumusan Masalah}

1. Bagaimana Aktualisasi tata nilai 'PASTI' dalam pelaksanaan tugas dan fungsi dari satuan kerja di lingkungan Kemenkumham terutama dalam mendukung program Percepatan Pemberantasan dan Pencegahan Korupsi?

2. Apakah Sumber Daya Manusia yang ada di Kemenkumham dapat melaksanakan tata nilai dan program 'PASTI', serta dapat memberikan kontribusi dalam mewujudkan Wilayah Bebas dari Korupsi dan Wilayah Birokrasi Bersih dan Melayani (WBK dan WBBM)?

3. Apa faktor penghambat dalam pemenuhan indikator WBK dan WBBM di lingkungan Kementerian Hukum dan HAM?

\section{Tujuan}

1. Untuk menganalisis aktualisasi tata nilai 'PASTI' dalam pelaksanaan tugas dan fungsi dari satuan kerja di lingkungan Kemenkumham terutama dalam mendukung program Percepatan pemberantasan dan pencegahan korupsi.

2. Untuk menganalisis kemampuan sumber daya manusia yang ada di Kemenkumham dapat melaksanakan tata nilai dan program 'PASTI', serta dapat memberikan kontribusi dalam mewujudkan Wilayah Bebas dari Korupsi dan Wilayah Birokrasi Bersih dan Melayani (WBK dan WBBM).

3. Untuk menjabarkan faktor penghambat dalam pemenuhan indikator WBK dan WBBM di lingkungan Kementerian Hukum dan HAM.

\section{Metode Penelitian}

\section{Pendekatan}

Penelitian ini merupakan penelitian kebijakan (Policy Research), yang bertujuan untuk merumuskan kebijakan yang harus dilakukan atas suatu kepentingan. Penelitian ini menggunakan pendekatan gabungan kualitatif yang dalam pengumpulan data dilakukan melalui pengumpulan data primer dan data sekunder. Data primer diperoleh melalui wawancara mendalam dengan beberapa narasumber yang kompeten dan pembagian kuesioner, sedangkan data sekunder diperoleh melalui dokumendokumen yang memiliki korelasi dengan tata nilai 'PASTI'. Aplikasi metode kualitatif dalam penelitian kebijakan dilakukan dengan menempuh langkah-langkah merumuskan masalah sebagai fokus studi penelitian kebijakan, mengumpulkan data lapangan, menganalisis data, merumuskan hasil studi, dan menyusun rekomendasi untuk perumusan kebijakan. 


\section{Metode Pengumpulan Data}

Data yang diperlukan dalam penelitian ini adalah data primer dan data sekunder. Prosedur pengumpulan data primer dalam penelitian ini dengan menggunakan kuesioner yang dibagikan langsung dan pedoman wawancara kepada responden yaitu jajaran pimpinan di Kanwil dan UPT untuk diisi jawabannya sesuai pertanyaan dalam rangka mendapatkan data yang dibutuhkan. Setelah kuesioner tersebut dibagikan, responden diberikan arahan dan petunjuk untuk pengisian instrumen. Responden dapat menjawab langsung kuesioner yang telah dibagikan menurut pengetahuan dan pemahaman serta pengalaman kerja yang telah dilaluinya dalam waktu lebih kurang 1 (satu) minggu, kemudian mengembalikan kuesioner itu kembali kepada peneliti. Data sekunder dapat dikumpulkan oleh peneliti melalui catatan ataupun permintaan datadata yang dibutuhkan dalam penelitian kepada Unit eselon I, Kanwil, dan UPT yang menjadi objek penelitian.

\section{Teknik Penarikan Sampel}

Populasi penelitian ini adalah Kantor Wilayah (Kanwil) di lingkungan Kementerian Hukum dan HAM RI yang berjumlah 33 Kanwil. Sebelum dilakukan secara purpossive judgment sampling, terlebih dahulu dilakukan stratifikasi Kanwil berdasarakan jumlah UPT. Setelah menjadi tiga strata, kemudian dipilih tujuh kantor wilayah sebagai lokus yang mewakili Kanwil ketiga strata tersebut dan sekaligus keterwakilan wilayah Barat, Tengah, dan Timur. Lokasi yang terpilih: Yogyakarta, NTT, Sumut, Jateng, Jabar, Sulsel, dan DKI Jakarta. Selain di Kanwil, pengambilan data juga dilakukan di UPTUPT. Dari Kanwil terpilih tersebut kemudian ditentukan secara purpossive judgment sampling untuk menentukan liima UPT yang mewakili UPT Keimigrasian dan UPT Pemasyarakatan. Responden pada Kanwil terpilih adalah unsur pimpinan di kanwil yaitu
Kakanwil, dan lima responden dari masingmasing divisi. Sementara, dari UPT Imigrasi dan UPT Pemasyarakatan ditentukan Kepala UPT dan lima responden dari masing-masing UPT terpilih.

Datayangdikumpulkan dalammenunjang penelitian ini terdiri dari dua, yaitu: data primer yang langsung dikumpulkan oleh peneliti dari lapangan. Data ini merupakan jawaban dari kuesioner yang dibagikan kepada responden dan hasil wawancara. Data sekunder merupakan data yang bukan berasal dari sumber pertamanya, diperoleh dari arsip-arsip atau dokumen lainnya yang dibutuhkan dalam penelitian ini. Menurut Arikunto, "sumber data dalam Penelitian adalah subjek dari mana data dapat diperoleh". ${ }^{7}$ Mengingat penelitian ini difokuskan pada tata nilai 'PASTI' untuk mewujudkan WBK dan WBBM di Unit eselon I, Kanwil, dan UPT maka sumber data dalam penelitian ini diperoleh dari Unit eselon I, Kanwil, dan UPT Kemenkumham.

\section{Teknik Analisis Data}

Dari data yang telah terkumpul kemudian dilakukan analisis secara kualitatif untuk menjawab pertanyaan penelitian yang telah dilakukan Uji Coba Instrumen. Uji coba instrumen dilakukan untuk menentukan tingkat kesahihan dan kehandalan instrumen yang sudah disusun dengan melakukan uji validitas dan reliabilitas. Analisis yang digunakan lebih menekankan pada aspek pemahaman secara mendalam terhadap Aktualisasi tata nilai 'PASTI'. Analisis ini lebih menggunakan teknik analisis mendalam (indepth analysis), yaitu menganalisis masalah secara kasus perkasus karena metodologi kulitatif yakin bahwa sifat suatu masalah satu akan berbeda dengan sifat dari masalah lainnya.

7 Arikunto, S., Prosedur Penelitian Suatu Pendekatan Praktik Ed Revisi. Jakarta: Rineka Cipta, 2010, hlm.172. 


\section{PEMBAHASAN}

\section{Aktualisasi Tata Nilai (Values) 'PASTl' Dalam Pelaksanaan Tugas dan Fungsi Dari Satuan Kerja di Lingkungan Kemenkumham Dalam Mendukung Program Percepatan Pemberantasan dan Pencegahan Korupsi}

Aktualisasi Tata Nilai 'PASTI' dalam pelaksanaan tugas dan fungsi dari satuan kerja di lingkungan Kemenkumham telah dicanangkan sejak tahun 2015. Sejauhmana program aktualisasi dilaksanakan dapat dilihat gambarannya melalui hasil tanggapan responden yang diperoleh sebanyak 124 orang yang merupakan Pegawai Negeri Sipil (PNS) yang bekerja di UPT dan Kanwil Kemenkumham.

\section{Aktualisasi Tata Nilai (Values) 'PASTI'}

Pegawai Kemenkumham sebagian besar telah mengetahui tata nilai (jargon) "Kami PASTI" di Kementerian Hukum dan HAM, namun demikian ternyata masih ada yang belum mengetahui tata nilai 'PASTI'. Seharusnya pegawai mengetahui tata nilai 'PASTI' karena tata nilai 'PASTI' di unit kerja responden sudah pernah dideklarasikan sejak tahun 2015. Walaupun UPT ada yang mendeklarasikan tahun 2016 dan tahun 2017. Para pegawaipun mengetahui dan memahami tata nilai 'PASTI' yang merupakan singkatan dari Profesional, Akuntabilitas, Sinergi, Transparan, dan Inovatif.

\section{a) Profesionalisme}

Nilai unsur perilaku utama profesional meliputi perilaku terpuji, berkompeten, dan berintegritas. ${ }^{8}$ Setelah pendeklarasian tata nilai 'PASTI' pegawai Kemenkumham berkomitmen menjadi Aparatur Sipil Negara yang profesional dan mengabdikan diri sepenuhnya. Terbentuknya aparatur profesional memerlukan pengetahuan dan

8 Moeljarto, Tjrokrowinoto. Pemberdayaan: Konsep, Implementasi dan Kebijakan, Jakarta: CSIS, 1996, hlm.191. keterampilan khusus yang dibentuk melalui Pendidikan dan pelatihan sebagai instrumen pemutakhiran. ${ }^{9}$ Walau tidak mudah untuk menerapkannya, pegawai di UPT responden selalu berusaha untuk melakukan yang terbaik sesuai tugas dan fungsi. Dalam melaksanakan tata nilai 'PASTI' pegawai UPT menyatakan melakukan tanpa ada tekanan dari manapun dan dari siapapun. Tentunya setelah pendeklarasian tata nilai 'PASTI' sikap dan perilaku berbeda dengan sebelum pendeklarasian. Misalnya berkaitan dengan sikap tepat waktu. Ketaatan terhadap jam masuk kerja dan jam keluar kerja sudah lebih tepat waktu. Begitu juga dengan penyelesaian pekerjaan sesuai dengan aturan yang ditetapkan.

Kemudian untuk tingkat kemampuan pribadi, pegawai sudah dapat menerima jika dinilai oleh organisasi atau rekan sekerja, karena kemampuan dan keahlian yang terbentuk juga harus diikuti dengan perubahan iklim dalam dunia birokrasi yang cenderung bersifat kaku dan tidak fleksibel. ${ }^{10}$ Para pegawai selalu bertanggung jawab atas pekerjaan yang dilakukan, dan tidak akan lari dari kewajiban pekerjaan yang diberikan. Para pegawai mempunyai keyakinan jika bekerja dengan profesional, publik akan percaya dengan unit kerja mereka.

Para pegawai di UPT responden juga mampu percaya diri sebagai Aparatur Sipil Negara walau banyak rintangan yang dihadapi dalam melaksanakan tata nilai 'PASTI'. Para pegawai telah mampu menjalin komunikasi dengan baik terhadap rekan sekerja dan selalu mendukung keputusan dari organisasi profesinya.

$9 \quad$ Sondang Siagian, Manajemen Sumber Daya Manusia, Jakarta: Ghalia Indonesia, 2000, hlm.163.

10 Tangkilisan, Hessel Nogi S., Manajemen Public, Jakarta: Gramedia widiasarana Indonesia, 2005, hlm.221. 


\section{b) Akuntabilitas}

Nilai unsur perilaku utama akuntabilitas memiliki perilaku bertanggung jawab, berkinerja tinggi, dan berkesinambungan. Akuntabilitas pada unit kerja berkaitan dengan laporan keuangan. Akuntabilitas menunjuk pada institusi tentang "checks and balance" dalam sistem administrasi. ${ }^{11}$ Menurut sebagian besar pegawai unit kerja menyatakan bahwa isi laporan keuangan yang disampaikan telah sesuai dengan ketentuan yang ada. Hasil yang telah dicapai untuk program jangka panjang selalu disajikan dalam Laporan pertanggungjawaban (LPJ) satuan kerja sesuai dengan Standar Akutansi Pemerintah (SAP). Laporan pelaksanaan anggaran secara berkala disampaikan kepada Unit Eselon I dan publik. Laporan pelaksanaan anggaran selalu disampaikan kepada Unit Eselon I secara tepat waktu. Setiap akhir tahun anggaran dapat diakses oleh semua pihak berkepentingan untuk melihat pelaksanaan anggaran tahun yang lalu.

Aparatur Sipil Negara satuan kerja, serta masyarakat selalu dilibatkan dalam penyusunan rencana penganggaran maupun perubahannya agar mencerminkan kinerja pengelolaan keuangan satuan kerja yang efektif dan efisien. Penganggaran yang dilakukan telah menampung aspirasi masyarakat. Mengenai pelaksanaan standar pembuatan keputusan program di unit kerja sudah dikoordinasikan kepada kantor wilayah melalui bagian program dan penganggaran. Sebuah keputusan tentang program di unit kerja, tersedia bagi warga yang membutuhkannya, karena keputusan mengenai program unit kerja telah sesuai dengan prinsip-prinsip administrasi yang benar.

11 Joko Widodo, Good Governance (Telaah dan Dimensi Akuntabilitas dan Kontrol Birokrasi Pada Era Desentralisasi dan Otonomi Daerah), Surabaya: Insan Cendekia, 2001, hlm. 148.
Sasaran kebijakan yang diambil juga telah berdasarkan visi dan misi unit kerja. Penyajian informasi yang berhubungan dengan caracara mencapai sasaran suatu program sudah cukup akurat dan lengkap. Sementara sasaran kebijakan yang telah diambil juga sudah cukup jelas dan tepat sasaran. Produkproduk kebijakan yang dibuat oleh unit kerja sesuai dengan kebijakan yang dibuat oleh Kementerian. Laporan pertanggungjawaban unit kerja diinformasikan melalui media massa. Unit kerja juga memberikan laporan pengelolaan keuangan kepada pihak-pihak terkait (stakeholders). Begitu juga dengan pengadaan barang dan jasa unit kerja sudah sesuai dengan keputusan dan mekanisme yang ada. Hal ini memang harus dilakukan karena akuntabilitas merupakan kewajiban untuk memberikan pertanggungajawaban atau menjawab dan menerangkan kinerja atas tindakan seseorang/badan hukum/ pimpinan suatu organisasi kepada pihak yang memiliki hak atau kewenangan untuk meminta keterangan atau pertanggungjawaban dapat direalisasikan. ${ }^{12}$

\section{c) Sinergi}

Nilai unsur perilaku utama sinergi meliputi perilaku bekerja sama, bermitra, dan solutif. Sinergi merupakan strategi unit kerja dalam pelaksanaan program dengan unit kerja lain telah secara terus-menerus dilakukan. Sinergi adalah sebuah proses dimana interaksi dari dua atau lebih agen atau kekuatan akan menghasilkan pengaruh gabungan yang lebih besar dibandingkan jumlah dari pengaruh mereka secara individual. ${ }^{13}$ Pengembangan 'Management Development Program' untuk

12 Lembaga Administrasi Negara dan Badan Pengawasan Keuangan dan Pembangunan, Akuntabilitas dan Good Governance" Lembaga Admnistrasi Negara dan Badan Pengawas Keuangan dan Pembangunan, Jakarta, 2000, hlm. 43.

13 Deardorff, D.S., \& Williams, G., Synergy Leadership in Quantum Organizations, Fesserdorff Consultants, 2006. Available from: http://www.fesserdorff. com. 
menumbuhkan pemimpin baru dari internal juga telah dilakukan dengan menerapkan proyek perubahan. Fokus pengembangan pada unit kerja yang kuat pada pembekalan pribadi SDM, sebab jika SDM kuat unit kerja dapat melaksanakan tugas dan fungsi dengan baik. SDM telah didorong untuk selalu bekerja sama walaupun dari paradigma (pola pikir) yang berbeda. Hal ini dilakukan untuk mewujudkan hasil yang lebih besar dan efektif dalam pelaksanaan tugas yang dijalani. Selain itu, unit kerja berupaya untuk memadukan bagian-bagian yang terpisah.

\section{d) Transparansi}

Transparansi merupakan prinsip yang menjamin akses atau kebebasan bagi setiap orang untuk memperoleh informasi tentang penyelenggaraan pemerintahan, yakni informasi tentang kebijakan proses pembuatan dan pelaksanaanya serta hasilhasil yang dicapai. ${ }^{14}$ Nilai unsur perilaku utama transparansi meliputi perilaku informatif dan aksesibilitas. Kepala satuan kerja telah mensosialisasikan dan memublikasikan program serta kebijakan satuan kerja kepada pegawai dan masyarakat. Pada program dan kebijakan satuan kerja telah tertera jelas tujuan dari anggaran. Dalam menyampaikan informasi, setiap informasi yang disajikan dalam laporan pertanggungjawaban telah mengungkapkan seluruh informasi yang diperlukan.

Informasi mengenai laporan pertanggungjawaban satuan kerja telah tersedia untuk umum. Laporan keuangan satuan kerja telah disampaikan secara terbuka kepada semua pihak, baik kepada ASN maupun kepada masyarakat. Informasi mengenai penganggaran telah tersedia untuk umum. Bahkan informasi mengenai target, kinerja keuangan satuan kerja, serta prosedur yang ada telah tersedia untuk umum. Namun,

14 Bappenas dan Depdagri, Buku Pedoman Penguatan Pengamanan Program Pembangunan Daerah, 2002, hlm.18. perlu dicatat bahwa informasi ini bukan sekedar tersedia, tapi juga relevan dan bisa dipahami publik. Selain itu, transparansi dapat membantu untuk mempersempit peluang korupsi di kalangan para pejabat publik dengan "terlihatnya" segala proses pengambilan keputusan oleh masyarakat luas. ${ }^{15}$

Akses informasi yang disediakan oleh unit kerja sesuai dengan fakta dan berdasarkan analisis keputusan-keputusan kebijakan yang telah diambil. Mekanisme pengaduan jika terdapat pelanggaran dalam penggunaan biaya anggaran dengan kotak pengaduan, melalui SMS, dan melalui media elektronik lainnya. Unit kerja belum sepenuhnya melibatkan masyarakat dan pihak-pihak terkait dalam membuat sebuah kebijakan. Unit kerja telah menjalin kerja sama dengan media massa dan lembaga non-pemerintahan dalam meningkatkan arus informasi kebijakan, karena keterbukaan informasi diharapkan akan menghasilkan persaingan yang sehat, toleran, dan kebijakan dibuat berdasarkan preferensi publik. ${ }^{16}$

\section{e) Inovatif}

Nilai unsur perilaku utama inovatif meliputi perilaku insiatif, kreatif, inspiratif, dan pembaharuan. Unit kerja telah melakukan inovasi dengan pengembangan programprogram proyek perubahan yang fokus pada melayani masyarakat. Cara berpikir sebagian besar pegawai selalu berorientasi terhadap masa depan karir. Program inovasi memiliki keunggulan dibandingkan dengan program yang dimiliki sebelumnya. Dengan inovasi dapat menciptakan sumber daya

15 Max H. Pohan, Mewujudkan Tata Pemerintahan Lokal yang Baik (Local Good Governance) dalam Era Otonomi Daerah, Jakarta: Badan Perencanaan Pembangunan Nasional (Bappenas), 2000, hlm. 2.

16 Meutiah Ganie Rahman, "Good Governance Prinsip, Komponen, dan Penerapannya" dalam Hak Asasi Manusia (Penyelenggaraan Negara Yang Baik), Jakarta: Penerbit Komnas HAM, 2000, hlm .151 
baru maupun pengelolaan sumber daya yang ada dengan peningkatan nilai potensi untuk menciptakan sesuatu yang tidak ada menjadi ada. $^{17}$

Program inovasi yang dilakukan satu unit kerja, masih sesuai dengan yang dikeluarkan oleh unit kerja lain. Program inovasi yang dilakukan dapat memudahkan untuk melakukan kegiatan dan membuat menjadi praktis. Setelah penerapan 'PASTI' unit kerja telah memiliki program kerja berbeda dengan yang sebelumnya. Para pegawai juga sudah mulai terbuka terhadap pengalaman baru. Unit kerja berusaha tidak kehabisan ide dalam memecahkan masalah untuk pelaksanaan kegiatan dengan memperoleh gagasan dan ide yang berasal dari pemikiran pegawai. Seperti yang dikatakan Adair, inovasi merupakan proses menemukan dan mengimplementasikan sesuatu yang baru ke dalam situasi yang baru. ${ }^{18}$

\section{Tata Nilai (Values) sebagai Upaya Pemberantasan Korupsi}

Analisis terhadap jawaban para responden atas pertanyaan yang diajukan, membuktikan dugaan awal permasalahan yang dihadapi adalah persepsi yang salah tentang beberapa perbuatan yang sesungguhnya merupakan korupsi tapi selama ini dilakukan karena menganggap hal tersebut merupakan kewajaran dan kelaziman dalam hubungan bermasyarakat dan berbangsa.

Untuk itu, 'Tim Tunas Integritas' memberikan pembekalan tentang tindak pidana korupsi dan cara berperan serta dalam upaya pemberantasannya, baik represif maupun preventif. Pembekalan dilakukan dengan cara ceramah yang diikuti dengan kegiatan permainan dan tanya jawab. Para

17 Drucker Petter, Innovation and Entrepreneurship, New York: Harper Dan Row, 1985, hlm. 20.

18 Adair. J., Effective Innovation: How to Stay Ahead of the Competition. London: Pan Books Ltd., 1996. pegawai masih minim pengetahuan tentang tindak pidana korupsi dan cara berperan serta dalam penanggulangannya. Namun dari pertanyaan yang diajukan juga dipahami bahwa pegawai memahami bahwa upaya pemberantasan korupsi membutuhkan kerja sama semua pihak.

Tanggapan pegawai terhadap nilai- nilai 'PASTI' dan nilai-nilai anti korupsi yang disampaikan oleh agen perubahan beragam. Pada umumnya pegawai memahami bahwa nilai-nilai kejujuran, keterbukaan, kepercayaan diri, serta disiplin adalah nilainilai umum yang seharusnya dimiliki oleh semua pegawai. Tetapi bukan hal yang mudah untuk menerapkan nilai-nilai tersebut dalam kehidupan di masyarakat sekarang ini. Terutama jika berkenaan dengan masalah di kantor atau menyangkut pekerjaan.

Pengalaman empiris para pegawai memperlihatkan bahwa orang-orang yang jujur dalam pekerjaan seringkali tersingkir, dan karir mereka berjalan tidak mulus atau cenderung "tidak terpakai". Secara financial mereka yang jujur juga seringkali minim, karena hanya menerima gaji semata, tanpa ada tambahan lain. Upaya pemberantasan korupsi harus dimulai dari pejabat/atasan di kantor, dengan memberi contoh yang baik tentang perilaku yang anti korupsi. Dengan demikian para bawahan akan mengikuti tindakan atasannya, dengan berbagai alasan, paling tidak pertama sekali karena alasan takut kepada atasan.

Upaya pemberantasan korupsi masih harus melalui jalan yang panjang. Peran serta pegawai untuk memberantas korupsi tidak dapat diharapkan timbul begitu saja, tanpa ada upaya untuk memberi contoh kepada mereka bagaimana hal itu harus dilakukan. Hal ini sesuai dengan karakteristik masyarakat Indonesia yang bersifat patrimonial dengan dasar patron klien, dimana bawahan akan meniru semua perilaku atasannya, Jika atasan memberi contoh baik, maka akan baik 
pula perilaku bawahannya. Karenanya tidak mengherankan jika pegawai mengandalkan pejabat yang memulai dan memberi contoh bagaimana upaya pemberantasan korupsi harus dilakukan.

Selain itu pemahaman seperti ini bukanlah hal yang diharapkan dalam upaya pemberantasan korupsi. Memang pimpinan seharusnya menjadi teladan dalam pemberantasan korupsi, tetapi upaya peran serta pegawai dalam pemberantasan korupsi haruslah lahir dari kesadaran individual, yang didasari oleh nilai-nilai tertentu yang telah tertanam dalam diri mereka. Nilai-nilai tersebut diantaranya adalah kejujuran. Jika seseorang bersifat jujur yang dilandasai oleh keyakinan agama, bahwa apapun yang mereka lakukan dilihat oleh Tuhannya, maka dalam kesempatan apa pun mereka tidak akan berbuat tidak jujur. Sifat ini merupakan dasar untuk menolak perilaku korupsi, karena korupsi selalu berawal dari ketidakjujuran dan ketidaktransparan dalam segala hal.

Begitu pun dengan nilai-nilai lainnya seperti kepercayaan diri dan disiplin. Karakteristik ini sesungguhnya merupakan modal dasar bagi suatu bangsa yang akan membangun dan menjadi besar. Jika seseorang percaya akan kemampuan dirinya dalam meraih cita-cita atau keinginannya, maka dia tidak akan tergoda untuk mencari jalan pintas mencapai keinginan tersebut. Jalan pintas tersebut seringkali adalah jalan yang penuh jebakan koruptif, seperti menyuap, menyogok dan lain-lain. Sikap disiplin akan mendukung rasa percaya diri tadi, karena dengan terbiasa berdisiplin mereka mengerti bahwa sesuatu hanya bisa diraih dengan kerja keras, bukan dengan cara-cara gampang seperti menyuap atau menyogok tadi.

Persoalannya adalah bagaimana kita semua menanamkan nilai-nilai 'PASTI' dan nilai-nilai anti korupsi tersebut dalam diri kita sendiri, kemudian menularkannya kepada keluarga (isteri, suami, dan anakanak) serta kepada lingkungan sekitar kita, baik di rumah mau pun di tempat kerja. Selain dari penanaman nilai-nilai 'PASTI' dan nilai-nilai anti korupsi tersebut, adalah juga penting mensosialisasikan program 'PASTI' dan program anti korupsi dengan memberikan pengetahuan yang benar mengenai tindak pidana korupsi serta cara pencegahannya. Pengetahuan yang benar mengenai perbuatan yang termasuk korupsi akan menghindarkan mereka dari perilaku koruptif tersebut, apalagi jika dalam diri mereka sendiri juga sudah terdapat nilai-nilai anti korupsi tersebut. Sosialisasi program anti korupsi juga harus mencakup petunjuk tentang cara melaporkan atau tindakan yang harus dilakukan oleh mereka jika mengetahui ada tindak korupsi dalam lingkungannya.

\section{Implikasi Tata Nilai (Values) dan Program 'PASTI' dalam Mewujudkan Wilayah Bebas dari Korupsi dan Wilayah Birokrasi Bersih dan Melayani (WBK dan WBBM)}

Setiap kegiatan dalam rangka penyelenggaraan pemerintahan oleh aparat Kemenkumham dapat dipertanggungjawabkan kepada masyarakat sesuai dengan ketentuan atau peraturan yang berlaku. Komitmen untuk membangun dan memastikan hubungan kerja sama yang produktif serta kemitraan yang harmonis aparat Kementerian Hukum dan HAM dengan para pemangku kepentingan untuk menemukan dan melaksanakan solusi terbaik, bermanfaat dan berkualitas.

Kemenkumham menjamin akses atau kebebasan bagi setiap orang untuk memperoleh informasi tentang penyelenggaraan pemerintahan, yakni informasi tentang kebijakan, proses pembuatan dan pelaksanaannya, serta hasilhasil yang dicapai. Kemenkumham mendukung kreativitas dan mengembangkan inisiatif untuk selalu melakukan pembaharuan dalam penyelenggaraan tugas dan fungsinya. 
Pelaksanaan tata nilai "PASTI" (Profesional, Akuntabel, Sinergi, Transparan, dan Inovatif) adalah Gerakan "Ayo Kerja, Kami PASTI" sudah dilaksanakan secara menyeluruh dan dimulai serentak pada tanggal 1 Juni 2015 di 814 satuan kerja Kemenkumham di seluruh Indonesia. Pencanangan awal adalah melalui Apel Serentak di Unit Utama dan di seluruh Kantor Wilayah Kemenkumham. Selanjutnya dikeluarkan Instruksi Menteri Hukum dan HAM untuk masing-masing satuan kerja agar melakukan penyerahan dokumen pedoman kerja antara lain, Peraturan Menteri tentang Target Kinerja Tahun 2015, Surat Keputusan Menteri tentang Petunjuk Pelaksanaan Penganggaran, Pengelolaan Keuangan, dan Barang Milik Negara serta Laporan Kinerja, dan Instruksi Menteri tentang Pelaksanaan Kesepakatan Bersama Unit Eselon I dan Kantor Wilayah dalam Penyusunan Anggaran Tahun 2016.

Deklarasi "Ayo Kerja, Kami PASTI" oleh seluruh pegawai Kemenkumham dengan melaksanakan Target Kinerja yang disahkan melalui Peraturan Menteri. Program aksi untuk percepatan pemberantasan dan pencegahan korupsi yang telah diatur dengan beberapa peraturan perundang-undangan dan gerakan revolusi mental "Ayo Kerja, Kami PASTI" yang telah dicanangkan seharusnya terdapat benang merah yang saling bersinergi antara tata nilai 'PASTI' dengan Pemberantasan dan Pencegahan Korupsi (PPK) dalam suatu wadah yang disebut WBK dan WBBM. Hasil evaluasi Zona Integritas (ZI) menuju WBK/ WBBM yang telah dilakukan seperti berikut.

\section{a) Manajemen Perubahan}

Pada UPT yang dilakukan pendampingan untuk WBK/WBBM telah dibentuk Tim Kerja. Kepala unit kerja telah membentuk tim untuk melakukan pembangunan Zona Integritas. Penentuan anggota Tim selain pimpinan, sebagian besar dipilih melalui prosedur/ mekanisme yang jelas. Pada rencana kerja pembangunan Zona Integritas menuju WBK/ WBBM di UPT telah memiliki Dokumen Rencana Pembangunan Zona Integritas, dan dalam dokumen pembangunan terdapat target-target prioritas yang relevan dengan tujuan pembangunan WBK/WBBM.

Dalam hal Pemantauan dan Evaluasi Pembangunan WBK/WBBM, seluruh kegiatan pembangunan sudah dilaksanakan sesuai dengan rencana. Monitoring dan evaluasi terhadap pembangunan Zona Integritas tim internal atas persiapan dan pelaksanaan kegiatan unit kerja WBK/WBBM dilakukan bulanan. Serta, hasil monitoring dan evaluasi tim internal atas persiapan dan pelaksanaan kegiatan Unit kerja WBK/WBBM telah ditindaklanjuti.

Perubahan pola pikir dan budaya kerja telah dilakukan oleh Pimpinan UPT yang diajukan untuk memperoleh predikat WBK/ WBBM. Pimpinan berperan sebagai role model dalam pelaksanaan pembangunan WBK/WBBM dan memberi teladan nyata. Misalnya mengisi/mencatat kehadiran setiap hari seperti pegawai lain. UPT sudah menetapkan agen perubahan dan telah membangun budaya kerja dan pola pikir di lingkungan organisasi melalui pelatihan budaya kerja dan pola pikir. Sebagian besar anggota organisasi unit kerja terlibat dalam pembangunan Zona Integritas menuju WBK/ WBBM.

\section{b) Penataan Tatalaksana}

UPT telah membuat prosedur operasional tetap (SOP) untuk kegiatan utama. Semua SOP unit kerja telah mengacu peta proses bisnis dan juga melakukan inovasi yang selaras, serta unit kerja telah menerapkan seluruh SOP yang ditetapkan organisasi dan juga melakukan inovasi pada SOP yang diterapkan. Namun, belum semua SOP telah dievaluasi, sebagian besar SOP utama telah dievaluasi dan telah ditindaklanjuti berupa perbaikan SOP. 
Untuk melakukan pengukuran kinerja UPT telah menerapkan e-office. Unit kerja telah memiliki sistem pengukuran kinerja yang menggunakan teknologi informasi dan juga melakukan inovasi. Selain itu unit kerja, juga telah memiliki operasionalisasi manajemen SDM yang menggunakan teknologi informasi namun belum melakukan inovasi. Untuk pelayanan publik, unit kerja memberikan pelayanan kepada publik dengan menggunakan teknologi informasi namun belum melakukan inovasi. Serta unit kerja telah membuat laporan monitoring dan evaluasi terhadap pemanfaatan teknologi informasi dalam pengukuran kinerja unit, operasionalisasiSDM, dan pemberian layanan kepada publik setiap bulan. Sementara untuk kebijakan tentang keterbukaan informasi publik telah diterapkan, dan telah melakukan monitoring dan evaluasi pelaksanaan kebijakan keterbukaan informasi publik.

\section{c) Penataan Sistem Manajemen SDM}

Perencanaan kebutuhan pegawai UPT diharapkan sesuai dengan kebutuhan organisasi. Pada UPT pencanangan WBK/ WBBM kebutuhan pegawai yang disusun oleh unit kerja mengacu kepada peta jabatan dan hasil analisis beban kerja untuk masingmasing jabatan. Namun baru sebagian kecil penempatan pegawai hasil rekrutmen murni mengacu kepada kebutuhan pegawai yang telah disusun per jabatan. Walaupun monitoring dan evaluasi terhadap rekrutmen dan penempatan pegawai untuk memenuhi kebutuhan jabatan dalam organisasi telah memberikan perbaikan terhadap kinerja unit kerja.

Untuk Pola Mutasi Internal, dalam melakukan pengembangan karier pegawai, telah dilakukan mutasi pegawai antar jabatan sebagai wujud dari pengembangan karier pegawai. Semua mutasi pegawai antar jabatan telah memperhatikan kompetensi jabatan dan mengikuti pola mutasi yang telah ditetapkan organisasi dan juga unit kerja memberikan pertimbangan terkait hal ini. Unit kerja telah melakukan monitoring dan evaluasi terhadap kegiatan mutasi yang telah dilakukan dalam kaitannya dengan perbaikan kinerja.

Dalam pengembangan pegawai berbasis kompetensi unit kerja melakukan Training Need Analysis. Semua rencana pengembangan kompetensi pegawai telah mempertimbangkan hasil pengelolaan kinerja pegawai. Sementara saat ini persentase kesenjangan kompetensi pegawai dengan standar kompetensi yang ditetapkan sebesar $<25 \%$. Selain itu, sebagian besar pegawai di unit kerja telah memperoleh kesempatan/ hak untuk mengikuti diklat maupun pengembangan kompetensi lainnya. Dalam pelaksanaan pengembangan kompetensi, unit kerja telah melakukan upaya pengembangan kompetensi kepada sebagian besar pegawai (dapat melalui pengikutsertaan pada lembaga pelatihan, in-house training, atau melalui coaching, atau mentoring, dll). Unit kerja telah melakukan monitoring dan evaluasi terhadap hasil pengembangan kompetensi dalam kaitannya dengan perbaikan kinerja setiap bulan.

Terdapat penetapan kinerja individu yang terkait dengan kinerja organisasi. Sebagian besar ukuran kinerja individu telah memiliki kesesuaian dengan indikator kinerja individu pada level di atasnya. Pengukuran kinerja individu telah dilakukan secara bulanan. Hasil penilaian kinerja individu sebagian besar telah dijadikan dasar untuk pemberian reward (pengembangan karir individu, penghargaan dII).

Unit kerja telah mengimplementasikan seluruh aturan disiplin/kode etik/kode perilaku pegawai yang ditetapkan organisasi, namun belum membuat inovasi terkait aturan disiplin/ kode etik/kode perilaku yang sesuai dengan karakteristik unit kerja. Sistem informasi kepegawaian unit kerja telah dimutakhirkan 
secara berkala. Data informasi kepegawaian unit kerja telah dimutakhirkan secara bulanan.

\section{d) Penguatan Akuntabilitas}

Untuk penguatan akuntabilitas, pimpinan terlibat secara langsung pada saat penyusunan perencanaan dan pada saat penyusunan penetapan kinerja, serta memantau pencapaian kinerja secara berkala. Begitu juga dengan pengelolaan akuntabilitas kinerja, dokumen perencanaan sudah ada. Ini terlihat karena unit kerja telah memiliki seluruh dokumen perencanaan (Rencana Strategis, Rencana Kerja Tahunan dan Penetapan Kinerja); Seluruh dokumen perencanaan telah berorientasi hasil. Secara umum unit kerja memiliki Indikator Kinerja Utama (IKU) yang ditetapkan organisasi, namun belum membuat IKU tambahan yang sesuai dengan karakteristik unit kerja. Seluruh indikator kinerja unit kerja telah memenuhi kriteria ukuran keberhasilan yang baik. Begitu juga dengan laporan kinerja, unit kerja telah menyusun laporan kinerja tepat waktu. Seluruh pelaporan kinerja telah memberikan informasi tentang kinerja. Terdapat upaya peningkatan kapasitas SDM yang menangani akuntabilitas kinerja, sehingga pengelolaan akuntabilitas kinerja dilaksanakan oleh SDM yang kompeten.

\section{e) Penguatan Pengawasan}

Public campaign tentang pengendalian gratifikasi telah dilakukan secara berkala dan unit kerja telah mengimplementasikan pengendalian gratifikasi. Lingkungan pengendalian internal telah dibangun dengan melakukan public campaign secara berkala dan unit kerja telah melakukan penilaian risiko atas pelaksanaan kebijakan serta telah mengimplementasikan pengendalian gratifikasi. Unit kerja telah melakukan kegiatan pengendalian untuk meminimalisir risiko yang telah diidentifikasi sesuai dengan yang ditetapkan organisasi. Sistem Pengendalian Internal (SPI) tersebut telah diinformasikan dan dikomunikasikan kepada seluruh pihak terkait.

Kebijakan pengaduan masyarakat telah diimplementasikan sesuai dengan yang ditetapkan organisasi. Seluruh hasil penanganan pengaduan masyarakat ditindaklanjuti oleh unit kerja. Monitoring dan evaluasi atas penanganan pengaduan masyarakat dilakukan setiap bulan. Namun, baru sebagian hasil evaluasi atas penanganan pengaduan masyarakat telah ditindaklanjuti oleh unit kerja. Whistle blowing system sudah di-internalisasi di unit kerja. Unit kerja menerapkan sebagian besar kebijakan whistle blowing system sesuai dengan yang ditetapkan organisasi. Evaluasi atas penerapan Whistle Blowing System telah dilakukan per semester. Hasil evaluasi atas penerapan whistle blowing system sebagian besar telah ditindaklanjuti oleh unit kerja.

Unit kerja telah mengidentifikasi/ memetakan benturan kepentingan dalam tugas dan fungsi utama. Penanganan benturan kepentingan telah disosialisasikan/ internalisasi dan telah diimplementasikan ke sebagian besar unit kerja. Evaluasi atas penanganan benturan kepentingan telah dilakukan, walaupun tidak secara berkala namun sebagian besar telah ditindaklanjuti oleh unit kerja.

\section{f) Peningkatan Kualitas Pelayanan Publik}

Unit kerja memiliki kebijakan standar pelayanan yang ditetapkan organisasi, dan telah memaklumatkan seluruh standar pelayanan sesuai dengan yang ditetapkan organisasi. Terdapat SOP bagi pelaksanaan standar pelayanan, dan telah menerapkan seluruh SOP sesuai dengan yang ditetapkan organisasi, serta melakukan review dan perbaikan atas standar pelayanan. Pelatihan telah dilakukan dalam upaya penerapan Budaya Pelayanan Prima. Informasi tentang pelayanan mudah diakses melalui berbagai media, (misal: papan pengumuman, 
selebaran, dsb). Telah terdapat sistem punishment (sanksi)/reward bagi pelaksana layanan serta pemberian kompensasi kepada penerima layanan bila layanan tidak sesuai standar, namun belum diimplementasikan. Unit kerja sebagian besar telah memiliki sarana layanan terpadu/terintegrasi, dan telah melakukan pelayanan secara terpadu.

Unit kerja telah melakukan survei kepuasan masyarakat terhadap pelayanan, namun survei kepuasan masyarakat yang dilakukan terhadap pelayanan tidak berkala. Hasil survei kepuasan masyarakat dapat diakses secara terbuka. Hasil survei kepuasan masyarakat dapat diakses melalui beberapa media misal: papan pengumuman, selebaran. Belum seluruhnya dapat diakses melalui website, media sosial, media cetak, media televisi, radio, dsb). Unit kerja melakukan tindak lanjut atas sebagian besar hasil survei kepuasan masyarakat.

\section{Faktor Penghambat dalam Pemenuhan Indikator WBK dan WBBM di Lingkungan Kementerian Hukum dan HAM}

Faktor penghambat dalam pemenuhan indikator WBK dan WBBM di lingkungan Kementerian Hukum dan HAM seperti belum lengkapnya Standar Operasi Prosedur (SOP). Selain itu, kurangnya data pendukung di setiap UPT. Dalam setiap program, kegiatan telah dilaksanakan dengan baik, namun kelengkapan data pendukung seperti foto kegiatan dan notulen pertemuan belum sepenuhnya dilengkapi. Sehingga sangat mempengaruhi nilai WBK/WBBM. Sementara, dalam melengkapi indikator WBK/WBBM belum sepenuhnya didasarkan pada pembenahan organisasi dan pelayanan kepada masyarakat yang lebih baik.

Penghambat secara internal seperti belum seluruh UPT membuat target-target relevan dengan tujuan pembangunan WBK/WBBM. Belum seluruh kegiatan pembangunan Zona Integritas sesuai dengan rencana kegiatan. Selain itu, hasil survei kepuasan masyarakat yang dilakukan secara internal belum dipublikasikan secara terbuka, baik melalui website, papan pengumuman atau sarana publikasi lainnya, dan belum seluruhnya dibuat laporannya secara bulanan. Pencanangan unit kerja WBKMBBM telah dimulai sejak tahun 2015 dengan dilakukan pendampingan oleh Inspektorat Jenderal Kemenkumham. Namun, pada tahun 2016 hanya Unit Kerja Lembaga Pemasyarakatan Perempuan Semarang yang memperoleh predikat unit kerja WBK/WBBM.

Hal ini disebabkan oleh tidak adanya perlakuan khusus bagi unit kerja berpredikat WBK/WBBM, seperti dukungan anggaran serta reward terhadap pribadi dan unit kerja tersebut, sehingga membuat rendahnya semangat para pejabat dan pegawai di unit kerja pendampingan WBK/WBBM. Hal ini terlihat dari informasi laporan kompilasi hasil pelaksanaan evaluasi pembangunan zona integritas menuju WBKMBBM di lingkungan Kemenkumham yang dilakukan Inspektorat Jenderal pada tahun 2016. Terhadap 34 (tiga puluh empat) satuan kerja yang dievaluasi secara crash program terdapat 23 unit kerja menuju WBK/WBBM yang mendapat nilai di atas 70,00. Sementara terhadap 30 (tiga puluh) satuan kerja yang sebelumnya dilakukan pendampingan, terdapat 22 unit kerja menuju WBK/WBBM yang memperoleh nilai di atas 70,00 . Namun hanya satu yang memperoleh predikat unit kerja WBK/WBBM secara nasional pada tahun 2016, yaitu Lembaga Pemasyarakatan Perempuan Semarang dengan nilai 91,03. Selain itu, belum pernah dilakukan survei persepsi korupsi secara mandiri oleh unit kerja WBK/ WBBM sehingga unit kerja tidak mengetahui indeks persepsi korupsi internal yang menjadi salah satu indikator hasil dalam terwujudnya unit kerja WBK/WBBM. 


\section{PENUTUP}

\section{Kesimpulan}

Aktualisasi tata nilai 'PASTI' telah dilakukan di Kementerian Hukum dan HAM. Para pegawai sebagian besar telah mengetahui tata nilai 'PASTI' yang telah dideklarasikan sejak tahun 2015 dari tingkat pusat sampai ke UPT, dan memahami tata nilai 'PASTI' yang merupakan singkatan dari Profesional, Akuntabilitas, Sinergi, Transparan, dan Inovatif. Internalisasi diperkuat dengan membangun "Tunas Integritas Kemenkumham" secara nasional di setiap kantor wilayah. Dalam melaksanakan tata nilai 'PASTI' dilakukan tanpa ada tekanan dari mana pun dan dari siapa pun. Setelah pendeklarasian tata nilai 'PASTI' sikap dan tindakan yang dilakukan berbeda dengan sebelum pendeklarasian. Seperti sikap tepat waktu dan ketaatan terhadap jam masuk kerja dan jam keluar kerja sudah lebih tepat waktu, serta penyelesaian pekerjaan sesuai dengan aturan yang ditetapkan.

Setelah penerapan tata nilai 'PASTI' di unit kerja telah memiliki program kerja yang berbeda dengan yang sebelumnya. Para pegawai juga telah mulai terbuka terhadap pengalaman baru. Unit kerja berusaha tidak kehabisan ide dalam memecahkan masalah untuk pelaksanaan kegiatan dengan memperoleh gagasan dan ide yang berasal dari pemikiran pegawai.

Kebutuhan pegawai telah disusun dengan mengacu kepada peta jabatan dan hasil analisis beban kerja untuk masingmasing jabatan. Dalam hal penempatan pegawai, baru sebagian kecil penempatan pegawai hasil rekrutmen murni mengacu kepada kebutuhan pegawai yang telah disusun per jabatan. Untuk Pola Mutasi Internal, dalam melakukan pengembangan karier pegawai, telah dilakukan mutasi pegawai antar jabatan sebagai wujud dari pengembangan karier pegawai. Namun belum semua mutasi pegawai antar jabatan telah memperhatikan kompetensi jabatan dan mengikuti pola mutasi yang telah ditetapkan organisasi.

Dalam Pengembangan pegawai berbasis kompetensi, UPT telah melakukan Training Need Analysis. Semua rencana pengembangan kompetensi pegawai telah mempertimbangkan hasil pengelolaan kinerja pegawai. Sementara saat ini persentase kesenjangan kompetensi pegawai dengan standar kompetensi yang ditetapkan sebesar $<25 \%$. Selain itu, UPT telah melakukan upaya pengembangan kompetensi kepada sebagian besar pegawai (dapat melalui pengikutsertaan pada lembaga pelatihan, in-house training, atau melalui coaching, atau mentoring, dII) dan telah melakukan monitoring dan evaluasi terhadap hasil pengembangan kompetensi dalam kaitannya dengan perbaikan kinerja, namun belum dilakukan setiap bulan.

Sebagian besar ukuran kinerja individu telah memiliki kesesuaian dengan indikator kinerja individu level di atasnya. Hasil penilaian kinerja individu sebagian besar telah dijadikan dasar untuk pemberian reward (pengembangan karir individu, penghargaan, dII). Unit kerja telah mengimplementasikan seluruh 'aturan disiplin'/'kode etik'/'kode perilaku' pegawai yang ditetapkan organisasi namun belum membuat inovasi terkait 'aturan disiplin'/'kode etik'/'kode perilaku' yang sesuai dengan karakteristik unit kerja.

Faktor penghambat dalam pemenuhan indikator WBK dan WBBM di lingkungan Kementerian Hukum dan HAM adalah masih adanya UPT yang belum melengkapi Standar Opreasi Prosedur (SOP) dan kurangnya data pendukung di setiap kegiatan yang dilakukan UPT, seperti kelengkapan data pendukung foto kegiatan serta notulen pertemuan yang belum sepenuhnya dilengkapi. Selain itu, belum adanya perlakuan khusus bagi unit kerja WBK/WBBM seperti dukungan anggaran serta reward terhadap pribadi dan 
unit kerja yang berakibat pada rendahnya semangat para pejabat dan pegawai di unit kerja pendampingan WBK/WBBM.

\section{Saran}

1. Tunas Integritas Kemenkumham perlu meningkatkan internalisasi tata nilai 'PASTI' secara kontinu kepada pegawai Kemenkumham terutama menanamkan nilai-nilai anti korupsi.

2. Perlu menetapkan Kepala Unit Pelaksana Teknis (UPT) sebagai Tunas Integritas yang menjadi role model pada masing-masing UPT untuk mempercepat internalisasi tata nilai 'PASTI'.

3. Perlu memberikan dukungan anggaran dan sarana prasarana secara khusus kepada UPT yang sudah dalam pendampingan WBK/WBBM, sehingga UPT dapat mewujudkan predikat WBKMBBM dan menjadi Pilot project kepada UPT lain yang akan mendapat pendampingan menuju Unit kerja WBK/ WBBM.

4. Perlu membuat Kode Etik dan Kode perilaku atas internalisasi tata nilai 'PASTI' dalam pelaksanaan tugas dan fungsi pegawai Kemenkumham yang parameternya dikaitkan dengan perwujudan WBK/WBBM.

5. Seluruh UPT di Kementerian Hukum dan HAM perlu melengkapi Standar Operasional Prosedur (SOP) atas semua pelaksanaan tugas dan fungsinya serta perlu memperkuat data pendukung dalam setiap kegiatan untuk mendukung nilai WBK/WBBM.

\section{UCAPAN TERIMA KASIH}

Ucapan terima kasih penulis sampaikan kepada Bapak Yasmon selaku Kepala Pusat Pengkajian dan Pengembangan Kebijakan Periode September 2017 s.d. Maret 2018 serta Bapak Zulkifli selaku Kepala Pusat Pengkajian dan Pengembangan Kebijakan Periode 2 April s.d. 28 Desember 2018 yang selalu mendorong penulis untuk selalu berkarya dan menginspirasi terwujudnya karya tulis ini. Terima kasih juga penulis sampaikan kepada Mitra Bestari (Reviewer) yang telah memberikan masukan terhadap karya tulis ini, sehingga karya tulis ini menjadi dapat memenuhi syarat untuk dipublikasikan secara luas. 


\section{DAFTAR PUSTAKA}

Adair. J., Effective Innovation: How to Stay Ahead of the Competition. London: Pan Books Ltd. London: Pan Books Ltd., 1996.

Arikunto, S., Prosedur Penelitian Suatu Pendekatan Praktik Ed Revisi. Jakarta: Rineka Cipta, 2010.

Bappenas dan Depdagri, Buku Pedoman Penguatan Pengamanan Program Pembangunan Daerah, 2002.

Deardorff, D.S., \& Williams, G. Synergy Leadership in Quantum Organizations, Fesserdorff Consultants, 2006. Available from: http://www.fesserdorff.com.

Drucker Petter, Innovation and Entrepreneurship, New York: Harper Dan Row, 1985.

Indonesia, Peraturan Presiden Nomor 81 tahun 2010 tentang Grand Design Reformasi Birokrasi 2010-2025, Jakarta

Indonesia, Instruksi Presiden Nomor 2 tahun 2014 tentang Aksi Pencegahan dan Pemberantasan Korupsi, Jakarta.

Indonesia, Instruksi Presiden Nomor 5 Tahun 2004 tentang Percepatan Pemberantasan Korupsi.

Indonesia, Peraturan Pemerintah Nomor 55 Tahun 2012 tentang Strategi Nasional Pencegahan dan Pemberantasan Korupsi Jangka Panjang Tahun 20122025, Jakarta.

Indonesia, Peraturan Pemerintah Nomor 60 Tahun2008tentang Sistem Pengendalian Internal Pemerintah, Jakarta.

Indonesia, Peraturan Menteri PAN dan RB Nomor Nomor 52 Tahun 2014 Tentang Pedoman Pembangunan Zona Integritas Menuju Wilayah Bebas Dari Korupsi Dan Wilayah Birokrasi Bersih Dan Melayani di Lingkungan Instansi Pemerintah, Jakarta.

Indonesia, Peraturan Menteri Hukum dan HAM Nomor M.HH-01.PW.02.03 Tahun 2011 tentang Pedoman Penetapan
Wilayah Bebas Korupsi (WBK) Kementerian Hukum dan HAM, Jakarta.

Indonesia, Peraturan Menteri PAN dan RB Nomor 14 Tahun 2014 Tentang Pedoman Evaluasi Reformasi Birokrasi Instansi Pemerintah, Jakarta.

Indonesia, Peraturan Menteri Hukum dan HAM Nomor 7 Tahun 2015 tentang Rencana Strategis Kementerian Hukum dan HAM 2015 - 2019, Jakarta.

Indonesia, Peraturan Menteri PAN dan RB Nomor 14 Tahun 2017 Tentang Pedoman Survei Kepuasan Masyarakat Terhadap Penyelenggaraan Publik, Jakarta.

Joko Widodo, Good Governance (Telaah dan Dimensi Akuntabilitas dan Kontrol Birokrasi Pada Era Desentralisasi dan Otonomi Daerah), Surabaya: Insan Cendekia, 2001.

Kementerian Hukum dan HAM. "Refleksi Akhir Tahun Kemenkumham, Yasonna Beri Penghargaan 10 Satker Berpredikat WBK". In https://kemenkumham. go. id/ berita/ refleksi-akhir-tahunkemenkumham-yasonna-beripenghargaan-10-satker-berpredikatwbk. Last update by 27 December 2018 , Last access by 15 March 2019

Lembaga Administrasi Negara dan Badan Pengawasan Keuangan dan Pembangunan, Akuntabilitas Dan Good Goverenance”, Jakarta: Lembaga Admnistrasi Negara dan Badan Pengawas Keuangan dan Pembangunan, 2000.

Max H. Pohan, Mewujudkan Tata Pemerintahan Lokal yang Baik (Local Good Governance) dalam Era Otonomi Daerah, Jakarta: Badan Perencanaan Pembangunan Nasional (Bappenas), 2000.

Meutiah Ganie Rahman, "Good Governance, Prinsip, Komponen, dan Penerapanya" dalam Hak Asasi Manusia (Penyelenggaraan Negara Yang Baik), Jakarta: Penerbit Komnas HAM, 2000. 
Moeljarto, Tjrokrowinoto. Pemberdayaan: Konsep, Implementasi dan Kebijakan. Jakarta: CSIS, 1996.

Sondang Siagian, Manajemen Sumber Daya Manusia, Jakarta: Ghalia Indonesia, 2000.

Susana A.M., Implementasi Peningkatan Kinerja Melalui Merit Sistem Guna Melaksanakan Undang-Undang Aparatur Sipil Negara No.5 Tahun 2014 di Kementerian Hukum dan HAM, Jurnal Ilmiah kebijakan Hukum Volume 10, Nomor 2, Juli 2016.

Tangkilisan, Hessel Nogi S., Manajemen Publik, Jakarta: Gramedia Widia Sarana Indonesia, 2005. 